\title{
Investigation of structure formation in lithium silicate glasses on initial stages of nucleation
}

\author{
O.Savvova, O.Babich, M.Kuriakin, A.Grivtsova, V.Topchiy \\ Chair of Technology of Ceramics, Refractories, Glass and Enamels, \\ National Technical University "Kharkiv Polytechnic Institute", \\ 2, Kyrpychova Str., 61002 Kharkiv, Ukraine
}

Received November 25, 2016

\begin{abstract}
Modern state of developments and applications of high-strength glass-ceramic materials based on lithium silicate glasses has been analyzed. Perspectiveness of using glass-ceramics based on lithium disilicate as transparent armor for ground vehicles has been established. Features of structure formation of lithium disilicate glasses on initial stages of nucleation have been studied. It has been established that the formation of strengthened structure containing lithium disilicate and $\beta$-spodumene in conditions of low-temperature thermal treatment will allow the use developed materials as a base in obtaining transparent glass-ceramic.

Keywords: lithium silicate glasses, glass-ceramic materials, structure, nucleation, lithium disilicate, mechanical strength.

Проанализировано современное состояние разработок и применение высокопрочных стеклокристаллических материалов на основе литийсиликатных стекол. Установлена перспективность использования ситаллов на основе дисиликата лития в качестве прозрачной брони для деталей наземной техники. Исследованы особенности формирования структуры литийсиликатных стекол на начальных этапах зародышеобразования. Установлено, что формирование упрочненной ситализированной структуры с содержанием дисиликата лития и $\beta$-сподумена в условиях низкотемпературной термической обработки позволит использовать как основу при получении прозрачных бронеситаллов.
\end{abstract}

Дослідження формування структури літійсилікатних стекол на початкових етапах зародкоутворення. О.В.Саввова, О.В.Бабіч, М.О.Курякін, А.О.Гривцова, В.Л.Топчий.

Проаналізовано сучасний стан розробок та застосування високоміцних склокристалічних матеріалів на основі літійсилікатних стекол. Встановлено перспективність використання ситалів на основі дисилікату літію як прозорої броні для деталей наземної техніки. Досліджено особливості формування структури літійсилікатних стекол на початкових етапах зародкоутворення. Встановлено, що формування зміцненої ситалізованої структури з вмістом дисилікату літію та $\beta$-сподумену в умовах низькотемпературної термічної обробки дозволить використовувати як основу при одержанні прозорих бронеситалів.

\section{Introduction}

High-strength glass-ceramic materials based on lithium silicate glasses have found widespread use in optics [1], aerospace systems [2], land vehicles and aviation, in par- ticular, for obtaining high-performance optical materials [3], in dentistry [4] due to their elevated performance properties. During the past years, an increase in demand is observed for versatile materials capable of withstanding rapid mechanical attacks, 
Table 1. Transparent glass-ceramic materials and their application

\begin{tabular}{|c|c|c|c|c|}
\hline No. & System, nucleators & Crystalline phase & $\begin{array}{c}\text { Type of products } \\
\text { and their application }\end{array}$ & Country, Author \\
\hline 1 & $\underset{\mathrm{ZnO}}{\mathrm{Li}_{2} \mathrm{O}-\mathrm{Al}_{2} \mathrm{O}_{3}-\mathrm{SiO}_{2},}, \mathrm{ZrO}_{2}, \mathrm{TiO}_{2}$ & $\begin{array}{c}\text { betaSR RAл-quartz, } \beta \text { - } \\
\text { spodumene }\end{array}$ & $\begin{array}{l}\text { Kitchen appliances, } \\
\text { oven windows }\end{array}$ & $\begin{array}{c}\text { USA, } \\
\text { S.Peschiera [6] }\end{array}$ \\
\hline 2 & $\mathrm{Li}_{2} \mathrm{O}-\mathrm{Al}_{2} \mathrm{O}_{3}-\mathrm{P}_{2} \mathrm{O}_{5}-\mathrm{SiO}_{2}$ & $\beta$-eucryptite & Precision optics & $\begin{array}{c}\text { Russia, Alekseeva } \\
{[7}\end{array}$ \\
\hline 3 & $\mathrm{Al}_{2} \mathrm{O}_{3}-\mathrm{P}_{2} \mathrm{O}_{5}-\mathrm{SiO}_{2}$ & $\beta$-quartz & Integrated circuits & $\begin{array}{c}\text { USA, } \\
\text { K.K.Ohara [8] }\end{array}$ \\
\hline 4 & $\begin{array}{c}\mathrm{Li}_{2} \mathrm{O}-\mathrm{Ga}_{2} \mathrm{O}_{3}-\mathrm{Al}_{2} \mathrm{O}_{3}-\mathrm{SiO}_{2} \\
\mathrm{ZrO}_{2}, \mathrm{TiO}_{2}, \mathrm{ZnO}\end{array}$ & $\begin{array}{l}\text { aluminogalate spinel, } \\
\text { ganite, } \beta \text {-quartz }\end{array}$ & $\begin{array}{c}\text { Short-wave solid } \\
\text { lasers, color } \\
\text { displays, IR sensors } \\
\end{array}$ & $\begin{array}{l}\text { USA, Y.Wang, } \\
\text { M.Siroia, H.Beall } \\
\text { Georg [9-11] } \\
\end{array}$ \\
\hline 5 & $\begin{array}{l}\mathrm{MgO}-\mathrm{Al}_{2} \mathrm{O}_{3}-\mathrm{SiO}_{2} \\
\mathrm{TiO}_{2}, \mathrm{Cr}_{2} \mathrm{O}_{3}\end{array}$ & forsterite & $\begin{array}{l}\text { Amplifiers and } \\
\text { lasers in } \\
\text { telecommunication } \\
\text { systems }\end{array}$ & $\begin{array}{c}\text { USA, G.H.Beall } \\
{[12]}\end{array}$ \\
\hline 6 & $\begin{array}{c}\mathrm{Li}_{2} \mathrm{O}-\mathrm{Al}_{2} \mathrm{O}_{3}-\mathrm{SiO}_{2} ; \mathrm{ZrO}_{2}, \mathrm{TiO}_{2}, \\
\mathrm{SnO}_{2}, \mathrm{~V}_{2} \mathrm{O}_{5}, \mathrm{Cr}_{2} \mathrm{O}_{3}, \mathrm{CeO}_{2}\end{array}$ & $\begin{array}{l}\text { lithium disilicate, } \\
\text { cristobalite, spinel }\end{array}$ & \multirow[t]{2}{*}{ Armor materials } & $\begin{array}{l}\text { USA, } \\
\text { B.L.Rudoy [13] }\end{array}$ \\
\hline 7 & $\mathrm{Li}_{2} \mathrm{O}-\mathrm{SiO}_{2} ; \mathrm{P}_{2} \mathrm{O}_{5}, \mathrm{ZnO}, \mathrm{ZrO}_{2}$ & lithium disilicate & & $\begin{array}{l}\text { Great Britain, } \\
\text { A.Darrant [14] }\end{array}$ \\
\hline 8 & $\mathrm{Li}_{2} \mathrm{O}-\mathrm{MgO}-\mathrm{Al}_{2} \mathrm{O}_{3}-\mathrm{SiO}_{2}$ & spinel, $\beta$-quartz & $\begin{array}{c}\text { Sight glass of } \\
\text { special-purpose } \\
\text { vehicles } \\
\end{array}$ & $\begin{array}{c}\text { USA, } \\
\text { L.R.Pinckney [15] }\end{array}$ \\
\hline
\end{tabular}

which will be able to compete with more expensive ceramic counterparts. Solution to this problem is creation of readily producible impact-resistant lithium-silicate glassceramic materials, which are effectively used for protection against high-energy munitions and abrasive wear [5].

Known transparent glass-composite materials used in electronics, optics, domestic appliances, instrument engineering and transport, are predominantly obtained on the base of crystalline phases of $\beta$-spodumene [6], $\beta$-eucryptite [7], $\beta$-quartz [8], spinel, ganite [9-11] and forsterite [12]. A distinguishing characteristic of glass-ceramic material based on lithium disilicate $\left(\mathrm{LS}_{2}\right)$ [13, 14] and / or spinel [15] is the combination of mechanical strength to provide resistance against energy-destructive components and the ability to absorb and dissipate impact stresses (Table 1). This allows the using of transparent glass-ceramics based on $\mathrm{LS}_{2}$ for sight glass, shields, visors, and for manufacturing different types of personal protective equipment. Imparting the properties of absorbing electromagnetic radiation to glass-ceramic materials will allow decreasing the probability of detecting vehicles and personnel by electronic equipment. However, currently known impact-resistant glass-ceramic based on $\mathrm{LS}_{2}$ are characterized by rather long thermal treatment durations on nucleation stage $(24 \div 170 \mathrm{~h})$
[13, 14], and spinel-containing glass-ceramics are notable for high temperatures of melting, thermal treatment, and comparatively high density $\left(2.6 \div 2.8 \mathrm{~g} / \mathrm{cm}^{3}\right)$ [15]

Therefore, increasing reliability of protection of special-purpose vehicles, which are operated in high temperatures and mechanically stressed conditions, is a relevant task, a solution to which is developing compositions of lithium-silicate glasses and obtaining low-weight impact-resistant glass-ceramic materials of abovementioned purposes on their base in conditions of short-term lowtemperature thermal treatment.

\section{Experimental}

\subsection{Aim setting and research methods}

Important condition of providing high performance properties of glass-ceramic materials is a formation of high-strength structure by directed crystallization at low thermal treatment temperatures. Detailed investigations of crystallization process during heating of lithium silicate glasses were conducted in [16]. During the last years, a special focus in this institute has been given to the effect of nucleators $\mathrm{Pt}$ and $\mathrm{Au}$ on the kinetics of formation of lithium meta- and disilicates in photosensitive stoichiometric glasses with the content of $\mathrm{Li}_{2} \mathrm{O}=23.4 \div 35.0$ mole $\%$ [17]. However, an important factor in developing readily pro- 
Table 2. Chemical composition of model glasses, crystalline phases formed during their melting and thermal treatment

\begin{tabular}{|c|c|c|c|c|c|c|c|}
\hline \multirow[t]{3}{*}{ No. } & \multirow[t]{3}{*}{$\begin{array}{l}\text { Identifi- } \\
\text { cation }\end{array}$} & \multicolumn{3}{|c|}{$\begin{array}{c}\text { Chemical composition of model glasses, } \\
\text { mass. } \%\end{array}$} & \multirow[t]{3}{*}{$T,{ }^{\circ} \mathrm{C}$} & \multicolumn{2}{|c|}{$\begin{array}{l}\text { Characteristics of crystalline } \\
\text { phases in glass-ceramics after } \\
\text { single-stage thermal treatment }\end{array}$} \\
\hline & & \multicolumn{2}{|c|}{$\begin{array}{l}\text { Phase forming } \\
\text { components }\end{array}$} & Nucleators & & \multirow[t]{2}{*}{ Type } & \multirow[t]{2}{*}{$\begin{array}{l}\text { Amount, } \\
\text { vol. } \%\end{array}$} \\
\hline & & $\mathrm{Li}_{2} \mathrm{O}$ & $\mathrm{SiO}_{2}$ & $\mathrm{ZnO}, \mathrm{P}_{2} \mathrm{O}_{5}$, fluorides & & & \\
\hline 1 & SL-1 & 12.0 & 60.0 & $\mathrm{TiO}_{2}, \mathrm{ZnO}, \mathrm{P}_{2} \mathrm{O}_{5}$, & 1250 & $\mathrm{Li}_{2} \mathrm{SiO}_{3}$ & 30 \\
\hline 2 & SL-2 & 12.0 & 50.0 & $\mathrm{ZnO}, \mathrm{P}_{2} \mathrm{O}_{5}, \mathrm{ZrO}_{2}$ & 1200 & $\mathrm{Li}_{2} \mathrm{SiO}_{3}$ & 30 \\
\hline 3 & SL-3 & 11.0 & 71.8 & $\mathrm{ZnO}, \mathrm{CeO}_{2}$ & 1550 & $\beta$-LiAISi ${ }_{2} \mathrm{O}_{8}, \mathrm{ZrO}_{2}$ & 40 \\
\hline 4 & SL-4 & 20.0 & 65.0 & $\begin{array}{c}\mathrm{P}_{2} \mathrm{O}_{5}, \mathrm{TiO}_{2}, \mathrm{ZrO}_{2}, \mathrm{La}_{2} \mathrm{O}_{3} \\
\text { fluorides }\end{array}$ & 1280 & $\begin{array}{c}\mathrm{Li}_{2} \mathrm{SiO}_{3}, \beta-\mathrm{LiAlSi}_{2} \mathrm{O}_{6} \\
\mathrm{Li}_{2} \mathrm{MgSiO}_{4}\end{array}$ & 40 \\
\hline 5 & SL-5 & 13.0 & 60.0 & $\underset{\mathrm{La}, \mathrm{O}_{3}, \text { fluorides }}{\mathrm{P}_{2} \mathrm{O}_{5}, \mathrm{ZnO}, \mathrm{ZrO}_{2}, \mathrm{CeO}_{2}}$ & 1350 & $\mathrm{Li}_{2} \mathrm{SiO}_{3}, \beta-\mathrm{LiAISi}_{2} \mathrm{O}_{6}$ & 35 \\
\hline
\end{tabular}

ducible lithium-silicate glass-ceramics is, along with decreasing the content of silicon and lithium oxides, choosing inexpensive and effective nucleators, which allow formation of glass-ceramic structure at relatively low temperatures. Additionally, an efficient energy saving solution in developing glass-ceramic lithium disilicate-based materials is decreasing the time of thermal treatment on the nucleation phase.

To solve the above problem, an investigation of structure formation process of lithium-silicate glasses on initial stages of crystals nucleation is necessary, which constitutes the aim of this work.

Occurrence of crystalline phase was confirmed by X-Ray diffraction ("DRON-3M" diffractometer) and petrographic (NU-2E polarizing microscope) methods of analysis. Microstructure of the glasses was investigated with "EMV 100 AK" electron microscope and Specord-M80 spectrophotometer. Crystallization ability of glasses was determined by two methods: gradient-thermal method with one-stage mode in the temperature range of $400 \div 800^{\circ} \mathrm{C}$ during $6 \mathrm{~h}$, and bulk crystallization method at characteristic temperatures of glass-ceramic formation stages. Fracture viscosity was calculated based on the data obtained with hardness tester TMV-1000. Elasticity modulus was determined using the apparatus for the measuring by static method. Relative elongation of material upon $\left(\Delta t_{i}-t_{e}\right)$ was measured on vertical quartz dilatometer.
2.2. Development of compositions of lithium silicate glasses for obtaining glass-ceramic materials

To determine the compositional area of existence of initial materials, the system $\mathrm{R}_{2} \mathrm{O}-$ $\mathrm{LiF}-\mathrm{CaF}_{2}-\mathrm{RO}-\mathrm{RO}_{2}-\mathrm{R}_{2} \mathrm{O}_{3}-\mathrm{P}_{2} \mathrm{O}_{5}-\mathrm{SiO}_{2}$ has been selected. An area with the following concentration limits (mass. \%) was confined in it: $\mathrm{R}_{2} \mathrm{O} \sum\left(\mathrm{Na}_{2} \mathrm{O}, \mathrm{K}_{2} \mathrm{O}, \mathrm{Li}_{2} \mathrm{O}\right)-13.2 \div 20.0$; LiF - 0.0 $\div 3.5$; $\mathrm{RO} \sum(\mathrm{MgO}, \mathrm{ZnO})-0.0 \div 7.0 ; \mathrm{CaF}_{2}-0.0 \div 2.5$; $\mathrm{RO}_{2}-\sum\left(\mathrm{TiO}_{2}, \quad \mathrm{ZrO}_{2}\right)-0.0 \div 11.0 ;$ $\mathrm{R}_{2} \mathrm{O}_{3}-\sum\left(\mathrm{Al}_{2} \mathrm{O}_{3}, \quad \mathrm{~B}_{2} \mathrm{O}_{3}\right)-0.0 \div 7.0$; $\mathrm{P}_{2} \mathrm{O}_{5}-0.0 \div 3.48 ; \mathrm{SiO}_{2}-50.0 \div 71.8$ (Table 2), in which compositions of materials of SL series was synthesized. Additionally, the following components were added, mass. \%: $\mathrm{MnO}_{2}-0.0 \div 4.0, \mathrm{CeO}_{2}-0.0 \div 0.5$ and $\mathrm{La}_{2} \mathrm{O}_{3}-0.0 \div 5.0$.

Occurrence of $\mathrm{Na}_{2} \mathrm{O}$ and $\mathrm{K}_{2} \mathrm{O}$ in the experimental glasses allows to decrease their melting temperature and thermal treatment temperature significantly, as well as, along with $\mathrm{B}_{2} \mathrm{O}_{3}$ and $\mathrm{MnO}_{2}$, to decrease their density [18], which is an important condition of obtaining readily producible lightweight glassceramic materials. $\mathrm{TiO}_{2}, \mathrm{ZrO}_{2}$ and fluorides were chosen as nucleators. To form a fine crystalline interconnected structure by liquation mechanism, $\mathrm{P}_{2} \mathrm{O}_{5}$ was introduced to the composition of the initial glasses. Presence of $\mathrm{P}_{2} \mathrm{O}_{5}$ in the structure of the model glasses will allow, according to [19], to de- 


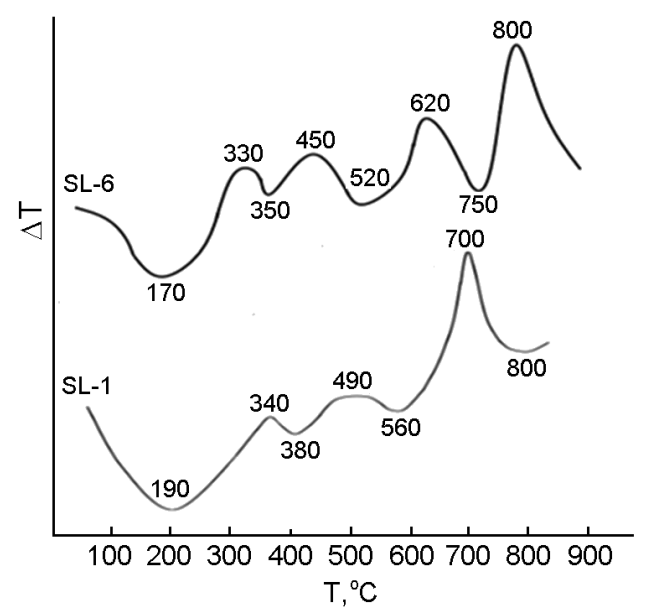

Fig. 1. Thermograms of model glasses.

crease deformation and stresses that arise due to absorption of impact energy. Introduction of $\mathrm{CeO}_{2}$ will provide nucleation reaction and formation of crystalline phases at lower temperatures, also promoting transparency of glass-ceramic materials. Presence of $\mathrm{La}_{2} \mathrm{O}_{3}$ in glasses will influence positively the increase of refractive index, which is an important prerequisite in obtaining glasses with optical performance.

Glasses of SL series were melted at similar conditions at $1200 \div 1550^{\circ} \mathrm{C}$ in corundum crucibles with subsequent cooling on a sheet of metal (Table 2).

2.3 Investigation of structure formation and phase composition of the vitreous materials during their thermal treatment

According to the data of X-ray diffraction analysis, model glasses are $\mathrm{X}$-ray amorphous after melting. The exception is SL-3 glass, which contains lithium metasilicate already after melting. After single stage treatment in gradient furnace, experimental vitreous materials have fine-grained structure with amount of crystalline phases $30 \div 40$ vol. \% (Table 2). Presence of crystalline phase of lithium disilicate $\approx 30 \mathrm{vol}$. $\%$ and $\beta$-spodumene $\approx 5$ vol. $\%$ is observed only of SL-6 glass, which was chosen for subsequent study.

Formation of volume-crystallized structure in SL-6 experimental glass is confirmed by DTA data (Fig. 1). Thus, thermogram of this glass has a narrow exothermic effect at $620^{\circ} \mathrm{C}$, which is related to possible formation of lithium disilicate and $\beta$-eucryptite crystals in it, the latter recrystallize to $\beta$-spodumene at $700 \div 800^{\circ} \mathrm{C}$.

This is confirmed by IR-spectra having a broad absorption bands with frequencies of

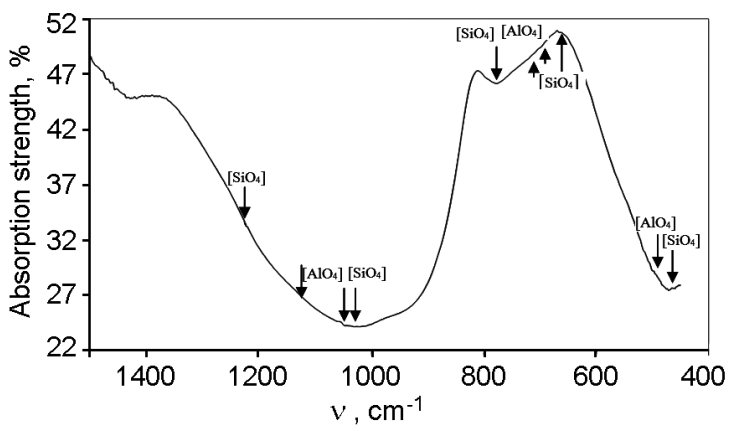

Fig. 2. IR-spectrum of SL-6 model glass.

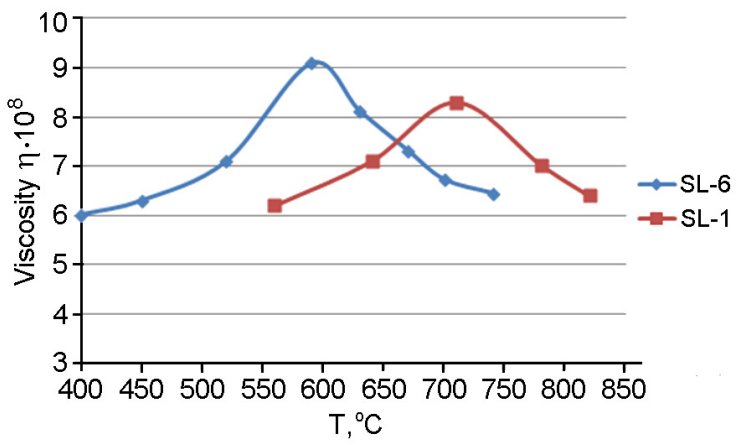

Fig. 3. Viscosity vs temperature dependence for experimental glasses.

471, 643, 786, 1021 and $1224 \mathrm{~cm}^{-1}$, which, according to A.Lazarev, are intrinsic for lithium disilicate (Fig. 2). In addition, insignificant absorption bands with frequencies $480,665,754,1040,1150 \mathrm{~cm}^{-1}$ are observed for this glass, which are intrinsic for $\left[\mathrm{AlO}_{4}\right]$ groups contained in $\beta$-eucryptite. Final formation of the structure similar to a glass-ceramic one, with presence of lithium disilicate and $\beta$-spodumene occurs at $800^{\circ} \mathrm{C}$.

In order to determine optimal values of viscosity in context of intensive fine crystallization of lithium disilicate on stage of nucleation and growth of crystalline phases, crystallization viscosities of SL- 6 glass and, for comparison purposes, SL-1 glass were investigated.

A distinctive feature of experimental glasses is anomalous increase of viscosity at glass transition range of $T_{g}-T_{f}$, which is related to the formation of fluctuations (Fig. 3).

The increase of crystallization viscosity $\eta=10^{8} \mathrm{~Pa} \cdot \mathrm{s}$ near temperature of $700^{\circ} \mathrm{C}$ for SL-1 glass is the evidence of intensive formation of nucleators and growth of metasilicate crystals. Decrease of the temperature to $620^{\circ} \mathrm{C}$, at which crystallization viscosity increases to $\eta=1.5 \cdot 10^{9} \mathrm{~Pa} \cdot \mathrm{s}$ for SL-6, results in glass spontaneously "choosing" those metastable crystalline phases that are 

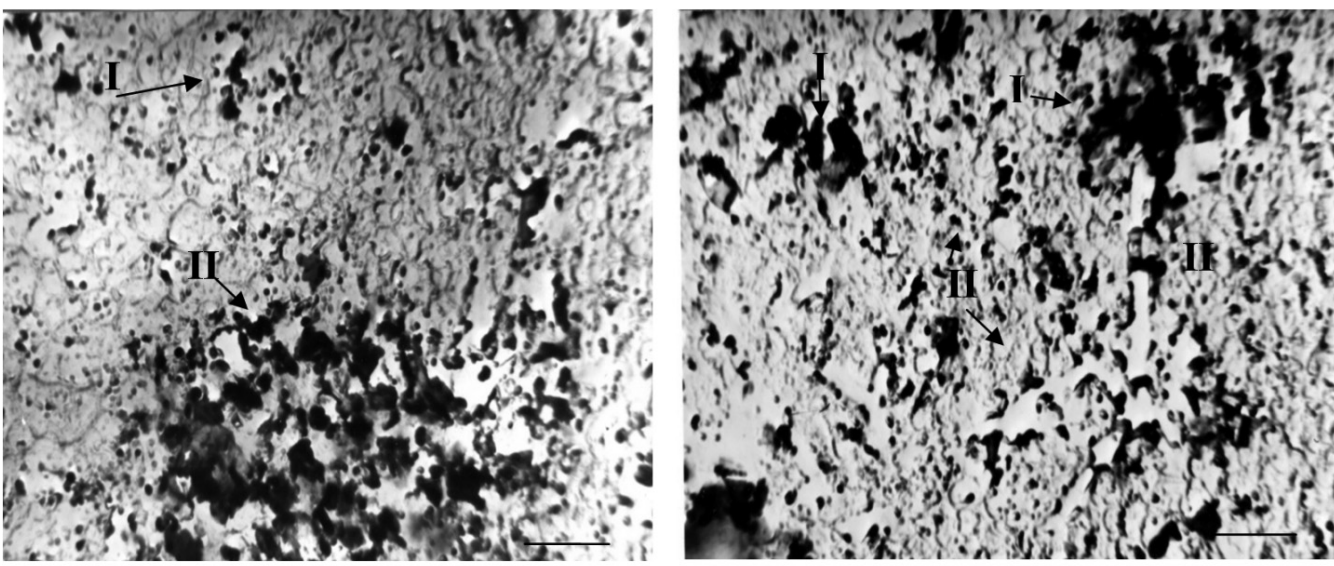

a)

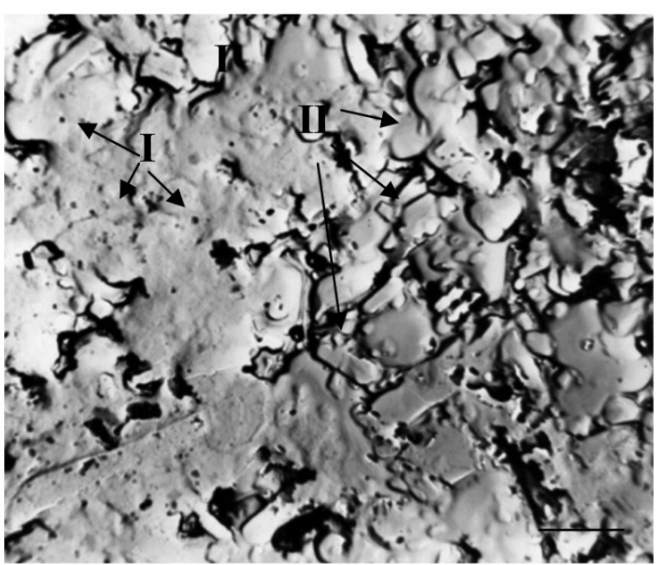

c)

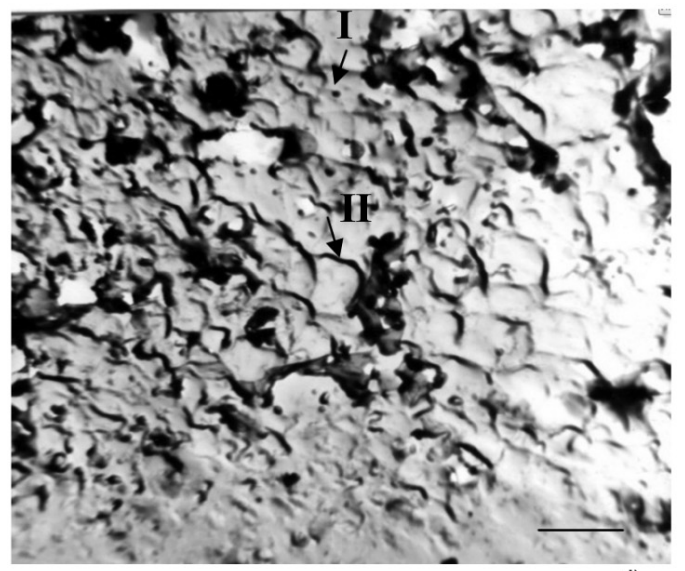

d)

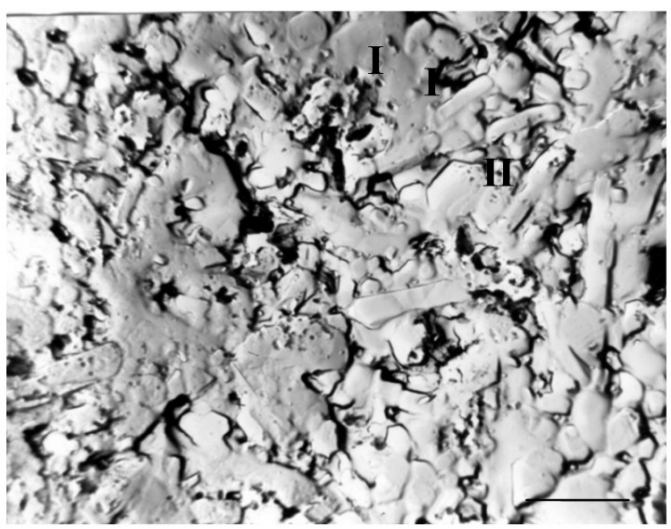

e)

Fig. 4. Structure of model vitreous material SL-6.

most easily wetted by it first, and, as a consequence, most tightly bound to it. However, high viscosity of the glass causes an important contribution to the kinetics of the process: the glass cannot separate into two phases in the observable time; formed vitreous phase creates fine droplets, which leads to formation of developed dropwise double-carcass structure in a short-term period [16].
To study the mechanism of nucleation and structure formation in the vitreous material, the following characteristic temperatures have been chosen: temperature $t_{1}$ below the softening onset temperature $T_{s o}$; temperature $t_{2}$ near $T_{s o}$; temperature $t_{3}$ above $T_{s o}$; temperature of "final" crystallization $t_{4}$. To identify the structure of vitreous material on initial stages of nucleation, sections with no crystallization were selected [16]. 
According to the results of electron microscopy, vitreous material SL- 6 at $t_{1}=500^{\circ} \mathrm{C}$ is a multiphase system formed from foundation glass, secondary dropwise nonuniformities with the size of $0.01 \sim 0.1 \mu \mathrm{m}$, which formed inside similar formations with the size of $\approx 0.5 \mu \mathrm{m}$ (Fig. 4a, I), and clusters of spherolites with the sizes of $0.5 \div 0.8 \mu \mathrm{m}$ (Fig. 4a, II), which according to F.Vogel [16], may be nucleators of lithium metasilicate.

Continuous growth of nonuniformities at $t_{2}=520^{\circ} \mathrm{C}$ in developed vitreous material is a distinctive characteristic of metastable liquation as a phase transition process [10]. Occurrence of clusters of nonuniformities in the form of cavities (Fig. 4b, I) and flattening of drops (Fig. 4b, II) is the evidence of completed phase separation process with subsequent process of structure ordering.

Upon heat-treating the experimental glass at $t_{3}=620^{\circ} \mathrm{C}$, along with occurrence of nano-nonuniformities (Fig. 4c, I), formation of crystals in the form of individualized three-dimensional spheres is observed (Fig. 4c, II). This may be related with the presence of $\mathrm{Li}_{2} \mathrm{O} \cdot 2 \mathrm{SiO}_{2}$ in the structure. According to V.Averyanov, lithium disilicate is crystallized in the form of spherolites at relatively low temperatures, which transform to monocrystals at higher temperatures. Determining influence of micro separation as a process that slows down the growth of spherolites in SL-6 glass with amount of $\mathrm{Li}_{2} \mathrm{O}=15$ mass. $\%$ is a formation of structure with isolated $2 \mathrm{Li}_{2} \mathrm{O} \cdot \mathrm{SiO}_{2}$ droplets. Effective limiting of sizes of lithium disilicate crystals should be expected in such glasses at elevated temperatures. On lithium disilicate crystallization, liquation nonuniformities are not destroyed, but their further growth is stopped. Therefore, on further thermal treatment of the glass at $t_{4}=800^{\circ} \mathrm{C}$, along with occurrence of nonuniformities (Fig. 4d, I), convex platelike or prismatic crystals of pseudo cubic habitus, $\mathrm{Li}_{2} \mathrm{O} \cdot 2 \mathrm{SiO}_{2}$ (Fig. 4d, II) are observed.

The choice of thermal treatment regime for SL-6 glass was based on the results of previous investigations [23]: Melting $1550^{\circ} \mathrm{C}$; I stage of thermal treatment $520^{\circ} \mathrm{C}, 10 \mathrm{~h}$; II stage $-620^{\circ} \mathrm{C}, 4 \mathrm{~h}$; III stage $-800^{\circ} \mathrm{C}, 4 \mathrm{~h}$. Increase of exposure time at the temperature of $520^{\circ} \mathrm{C}$ to $10 \mathrm{~h}$ leads to formation of a dense network of tabulated lithium disilicate crystals with the size of $0.5 \div 1.0 \mu \mathrm{m}$, bound on apexes at an angle (Fig. 4e, I) and 85 vol. \% of crystals with tabulated prismatic habitus bound on apexes, characteristic for $\beta$-spodumene (Fig. 4e, II). High-strength of glass-ceramic material, SL-6 $\left(K_{1 C}=3.0 \mathrm{MPa} \cdot \mathrm{m}^{1 / 2}, E=93 \mathrm{GPa}\right)$ with TKLE $\alpha_{\left(20-500^{\circ} \mathrm{C}\right)} \cdot 10^{7}=72.3 \mathrm{deg}^{-1}$, is due to the formation of such structure. This material can be used as a base in production of transparent impact-resistant glass-ceramic for protection of special-purpose vehicles.

\section{Conclusions}

Based on the results of conducted investigations, four-stage mechanism of structure and phase formation of glass-ceramic material in $\mathrm{R}_{2} \mathrm{O}-\mathrm{LiF}-\mathrm{CaF}_{2}-\mathrm{RO}-\mathrm{RO}_{2}-\mathrm{R}_{2} \mathrm{O}_{3}-$ $\mathrm{P}_{2} \mathrm{O}_{5}-\mathrm{SiO}_{2}$ system has been established. It has been found that on the first stage, upon the condition of providing the ratio of $\mathrm{SiO}_{2} / \mathrm{Li}_{2} \mathrm{O}=4$ and presence of 2 mass. \% $\mathrm{Al}_{2} \mathrm{O}_{3}$ in the glass melt, sybotaxic groups $\left[\mathrm{SiO}_{4}\right]$ and $\left[\mathrm{AlO}_{4}\right]$ are formed in the glass melt. On the second stage, upon cooling, a heterogeneous structure is formed by liquation mechanism, which leads to emergence of nucleators on the third stage in conditions of low-temperature thermal treatment $\left(520^{\circ} \mathrm{C}\right)$ and further growth of lithium disilicate crystals $\left(620^{\circ} \mathrm{C}\right)$ in the form of spherolites at viscosity of $\eta=10^{9} \mathrm{~Pa} \cdot \mathrm{s}$. On the fourth stage, at $800^{\circ} \mathrm{C}$, a glass-ceramic structure with the content of lithium disilicate and $\beta$-spodumene of 85 vol. $\%$ is formed. It has been established that mechanical and thermal properties $\left(K_{1 C}=\right.$ $3.0 \mathrm{MPa} \cdot \mathrm{m}^{1 / 2}, E=93 \mathrm{GPa}, \alpha_{\left(20-500^{\circ} \mathrm{C}\right)} \cdot 10^{7}=$ $72.3 \mathrm{deg}^{-1}$ ) of developed glass-ceramic material allow its use in production of transparent impact-resistant glass ceramics for protecting special-purpose vehicles.

\section{References}

1. M.V.Timoshenko, Ceramic Materials, BGMU, Minsk (2008) [in Russian].

2. Patent USA 6582826 (2003).

3. H.R.Fernandes, D.U.Tulyaganov, J.M.F.Ferreira, J. Mater. Sci., No 48, 765-773 (2013).

4. N.V.Suzdal, V.D.Khalilev, Glass and Ceramics, No.2, 10-12 (2004).

5. Patent RF 2176624 (2001).

6. Patent USA 7153795 (2006).

7. Patent RF (2008).

8. Patent USA 7226881 (2007).

9. Patent USA 5545595 (1996).

10. Patent USA 1736452 (2006).

11. Patent USA 6632758 (2003).

12. Patent USA 6632757 (2003).

13. Patent USA 4473653 (1984).

14. Patent GB 2379659 (2003). 
15. Patent USA 7875565 (2011).

16. N.A.Toropov, Structural Transitions in Glasses at Elevated Temperatures, Nauka, Moscow (1965) [in Russian].

17. G.A.Sycheva, Fizika $i$ Khimiya Stekla, 25, 327-336 (1999).
18. L.L.Bragina, Structure and Properties of Glass-Ceramic Materials, OOO Kompaniya SMIT, Kharkiv (2016).

19. A.I.Berezhnoy, Glass-ceramics and Photoglass-ceramics, Mashinostroyenie, Moscow (1966) [in Russian]. 